\title{
The Obesity Paradox - Some Methodological Considerations and Potential Physiological Mechanisms
}

\section{Grace FM, Buchan D, Kilgore L and Baker JS*}

Institute of Clinical Exercise and Health Sciences, University of the West of Scotland, Hamilton, South Lanarkshire, United Kingdom

The World Health Organization (WHO) estimates that over the past two decades, the incidence of obesity has tripled in developing countries, and it is predicted that there will be 2.3 billion overweight and 700 million obese individuals worldwide by 2015 [1]. This metabolic disorder is amongst the most significant public health problems faced by health services across the globe. Overweight is defined as a (BMI) of 25 to $29.9 \mathrm{~kg} / \mathrm{m}^{2}$ and obesity as a BMI $>30 \mathrm{~kg} / \mathrm{m}^{2}$. Overweight and obesity are both associated with increased morbidity and mortality, with even greater risk noted in extremely obese individuals with $\mathrm{BMI}>35 \mathrm{~kg} / \mathrm{m}^{2}$ [2].

Media outlets worldwide, reported a recently published systematic review and meta-analysis by Flegal et al. from the U.S. Centre for Disease Control [3], which reports Hazard Ratios (HR's) of all-cause mortality for overweight and obesity relative to normal weight in the general population. 97 studies were included in the analysis which provided a sample size of more than 2.88 million individuals and more than 270,000 deaths. The findings from this analysis were that, relative to normal weight (defined as BMI of $18.5-<25$ ), grades 2 and 3 obesity were associated with significantly higher all-cause mortality. Grade 1 obesity overall was not associated with higher mortality and overweight was associated with significantly lower all-cause mortality (HR, 0.94 (CI, 0.91-0.96)). The findings remained consistent following adjustment for smoking status, pre-existing disease, or weight and height reporting method. The study did not report or investigate physiological mechanisms for their findings.

The part of this study that stirred media interest was the research findings which suggest that being overweight confers the benefit of increased life expectancy. This is not a unique discovery. Previous corroborative studies identify a phenomenon termed "the obesity paradox"; wherein, overweight and obese subjects with established coronary artery disease, heart failure and hypertension and chronic obstructive pulmonary disease demonstrate an improved mortality risk [4-9]. These studies suggest that even though overweight and obesity increase the risk of disease development, once the disease develops, overweight and obese have better short and long term clinical outcomes when compared with leaner counterparts [10]. Although some authors have proposed potentially contributing factors, the underlying physiological mechanisms explaining the "obesity paradox" remain to be determined.

It has been well identified that development and distribution of body fat is closely regulated by gonadal function [11]. Women have higher body fat and tend to store body fat in the gluteofemoral region, whilst men tend have greater visceral body fat deposition. Following menopause, women develop a redistribution of body fat similar with the male profile with subsequent abolishment of protective oestrogenic effects [12]. This sex difference in body fat distribution has been identified as the main determinant of differing metabolic profiles and cardiovascular disease risk between men and women [11,12]. Indeed, the risk of developing obesity related diseases is significantly lower in premenopausal women compared to men, a difference which is negated following menopause [12]. A number of large scale studies have shown that between $30-50 \%$ of ageing obese men with type 2 diabetes have below the minimum normal testosterone threshold for men, [13-15] even when adjusted for age [16]. Systematic review of the topic has shown that High testosterone levels are associated with higher risk of type 2 diabetes in women but with lower risk in men [16]. The same review reported that men with higher testosterone levels had $42 \%$ lower risk of developing type 2 diabetes [16].

Further to existing sex hormone differences, It is postulated that being underweight is associated with an increased catabolic state with elevated levels of cytokines and imbalance in cortisol/ dehydroepiandrosterone ratio $[10,17]$ which may heighten hazard ratios relative to overweight and obese. In addition, adipose tissue is innervated with tumour necrosis factor- $\alpha$ receptors, which may help clear the circulating interleukin-1 and other cytokines conferring protective effects against mortality in heart failure and patients with cancer and other chronic illnesses [18,19]. Decreased natriuretic peptide levels have also been shown in obese patients with existing heart failure $[19,20]$. Visceral fat expansion can increase the clearance of active natriuretic peptides by means of an increased expression of clearance receptors on adipocytes, and in this way, it may contribute to the activity of the cardiac endocrine system [21], perhaps explaining, in part, why the 'obesity paradox' is more comprehensively described in heart failure studies.

Even though BMI is the most commonly used index for measuring obesity, in epidemiological and clinical studies, it does not always accurately reflect the true at-risk body fatness. In the recent past, many studies using other anthropometric measures, such as Waist Circumference (WC), Waist-To-Hip Ratio (WHR), percent body fat $(\% \mathrm{BF})$, and weight-to-height ratio, which take body-fat distribution into consideration, especially abdominal adiposity, have shown to perform better in predicting CV risk than BMI $[4,17]$. In fact, studies which do not corroborate the 'obesity paradox' phenomenon [22-24] usually employ other methods of body composition assessment. The fact remains that BMI measurement does not account for differences in sex, age, race or cardio-respiratory fitness levels between individuals. A recent study by McCauley et al. in men with documented or suspected coronary heart disease, cardiorespiratory fitness was found to greatly modify the relation of adiposity to mortality [25]. Also bearing in mind that BMI can a rather poor measure body composition in athletic and muscular individuals [26] simply using BMI to assess mortality risk in patients with or without existing CHD may be misleading unless fitness is considered.

To conclude, the so called "obesity paradox" characterisation has been around for the past decade in clinical medicine and

*Corresponding author: Dr. Julien Baker, Institute of Clinical Exercise and Health Sciences, University of The West of Scotland; Hamilton, South Lanarkshire, United Kingdom ML3 0JB, E-mail: jsbaker@uws.ac.uk

Received January 15, 2013; Accepted January 16, 2013; Published January 22 2013

Citation: Grace FM, Buchan D, Kilgore L, Baker JS (2013) The Obesity Paradox - Some Methodological Considerations and Potential Physiological Mechanisms. J Sports Med Doping Stud 3: e133. doi:10.4172/2161-0673.1000e133

Copyright: $\odot 2013$ Grace FM, et al. This is an open-access article distributed under the terms of the Creative Commons Attribution License, which permits unrestricted use, distribution, and reproduction in any medium, provided the original author and source are credited. 
Citation: Grace FM, Buchan D, Kilgore L, Baker JS (2013) The Obesity Paradox - Some Methodological Considerations and Potential Physiological Mechanisms. J Sports Med Doping Stud 3: e133. doi:10.4172/2161-0673.1000e133

Page 2 of 2

epidemiological studies though explanation of this phenomenon has been largely ignored. When interpreting epidemiological identification of this occurrence, it must be considered that there are also a number of studies that do not support the finding. Furthermore, statistical error may be inherent when one considers the method of classifying obesity. BMI measurement may contribute in inaccuracies in epidemiological studies where waist-hip ratio and radiographic techniques provide a better alternative, particularly when cardiorespiratory fitness may be a compounding factor. If the "obesity paradox" does exist then the most likely physiological explanation centres around the metabolic interaction between sex hormones, adipocytes and cellular metabolism, the identification of which are masked behind the cluster of metabolic dysfunctions of the metabolic syndrome. To further identify or refute the presence of the "obesity paradox" researchers should consider methodological classification of overweight and obesity in addition to a multi-disciplinary approach to underlying physiological mechanisms.

\section{References}

1. Haslam DW, James WP (2005) Obesity. Lancet 366: 1197-1209.

2. Alberti KG, Eckel RH, Grundy SM, Zimmet PZ, Cleeman JI, et al. (2009) Harmonizing the metabolic syndrome: a joint interim statement of the International Diabetes Federation Task Force on Epidemiology and Prevention National Heart, Lung, and Blood Institute; American Heart Association; World Heart Federation; International Atherosclerosis Society; and International Association for the Study of Obesity. Circulation 120: 1640-1645.

3. Flegal KM, Kit BK, Orpana H, Graubard BI (2013) Association of all-cause mortality with overweight and obesity using standard body mass index categories: a systematic review and meta-analysis. JAMA 309: 71-82.

4. Lavie CJ, Milani RV, Ventura HO (2009) Obesity and cardiovascular disease: risk factor, paradox, and impact of weight loss. J Am Coll Cardiol 53: 19251932.

5. Arena R, Lavie CJ (2010) The obesity paradox and outcome in heart failure: is excess bodyweight truly protective? Future Cardiol 6: 1-6.

6. Horwich TB, Fonarow GC, Hamilton MA, MacLellan WR, Woo MA, et al. (2001) The relationship between obesity and mortality in patients with heart failure. $J$ Am Coll Cardiol 38: 789-795.

7. Lavie CJ, Ventura HO, Milani RV (2008) The "obesity paradox": is smoking/lung disease the explanation? Chest 134: 896-898.

8. Galal W, van Gestel YR, Hoeks SE, Sin DD, Winkel TA, et al. (2008) The obesity paradox in patients with peripheral arterial disease. Chest 134: 925-930.

9. Wassertheil-Smoller S, Fann C, Allman RM, Black HR, Camel GH, et al. (2000) Relation of low body mass to death and stroke in the systolic hypertension in the elderly program. The SHEP Cooperative Research Group. Arch Intern Med 160: 494-500.

10. Lavie CJ, Milani RV, Artham SM, Patel DA, Ventura HO (2009) The obesity paradox, weight loss, and coronary disease. Am J Med 122: 1106-1114.
11. Blouin K, Boivin A, Tchernof A (2008) Androgens and body fat distribution. Steroid Biochem Mol Biol 108: 272-280.

12. Mattsson C, Olsson T (2007) Estrogens and glucocorticoid hormones in adipose tissue metabolism. Curr Med Chem 14: 2918-2924.

13. Dhindsa S, Prabhakar S, Sethi M, Bandyopadhyay A, Chaudhuri A, et al. (2004) Frequent Occurrence of Hypogonadotropic Hypogonadism in Type 2 Diabetes. $\mathrm{J}$ Clin Endocrinol Metab 89: 5462-5468.

14. Kapoor D, Aldred H, Clark S, Channer KS, Jones TH (2007) Clinical and Biochemical Assessment of Hypogonadism in Men With Type 2 Diabetes: Correlations with bioavailable testosterone and visceral adiposity. Diabetes Care 30: 911-917.

15. Grossmann M, Thomas MC, Panagiotopoulos S, Sharpe K, Macisaac RJ, et al. (2008) Low Testosterone Levels Are Common and Associated with Insulin Resistance in Men with Diabetes. J Clin Endocrinol Metab 93: 1834-1840.

16. Ding EL, Song Y, Malik VS, Liu S (2006) Sex differences of endogenous sex hormones and risk of type 2 diabetes: A systematic review and meta-analysis. JAMA 295: 1288-1299.

17. Artham SM, Lavie CJ, Milani RV, Ventura HO (2010) Value of weight reduction in patients with cardiovascular disease. Curr Treat Options Cardiovasc Med 12: $21-35$

18. Mohamed-Ali V, Goodrick S, Bulmer K, Holly JM, Yudkin JS, et al. (1999) Production of soluble tumor necrosis factor receptors by human subcutaneous adipose tissue in vivo. Am J Physiol 277: 971-975.

19. Rauchhaus M, Coats AJ, Anker SD (2000) The endotoxin-lipoprotein hypothesis. Lancet 356: 930-933

20. Mehra MR, Uber PA, Park MH, Scott RL, Ventura HO, et al. (2004) Obesity and suppressed B-type natriuretic peptide levels in heart failure. J Am Coll Cardio 43: 1590-1595

21. Clerico A, Giannoni A, Vittorini S, Emdin M (2012) The paradox of low BNP levels in obesity. Heart Fail Rev 17: 81-96.

22. Benderly M, Boyko V, Goldbourt U (2010) Relation of Body Mass Index to Mortality Among Men With Coronary Heart Disease. Am J Cardiol 106: 297 304.

23. Dagenais GR, Yi Q, Mann JF, Bosch J, Pogue J, et al. (2005) Prognostic impact of body weight and abdominal obesity in women and men with cardiovascula disease. Am Heart J 149: 54-60.

24. Romero-Corral A, Montori VM, Somers VK, Korinek J, Thomas RJ, et al. (2006) Association of bodyweight with total mortality and with cardiovascular events in coronary artery disease: a systematic review of cohort studies. The Lance 368: 666-678.

25. McAuley PA, Artero EG, Sui X, Lee DC, Church TS, et al. (2012) The Obesity Paradox, Cardiorespiratory Fitness, and Coronary Heart Disease. Mayo Clin Proc 87: 443-451.

26. Nevill AM, Stewart AD, Olds T, Holder R (2006) Relationship between adiposity and body size reveals limitations of BMI. Am J Phys Anthropol 129: $151-156$ 